TAPROBANICA, ISSN 1800-427X. January, 2015. Vol. 07, No. 01: pp. 62-65, pls. 24-25

(C) Research Center for Climate Change, University of Indonesia, Depok, Indonesia

\& Taprobanica Private Limited, Homagama, Sri Lanka

www.taprobanica.org

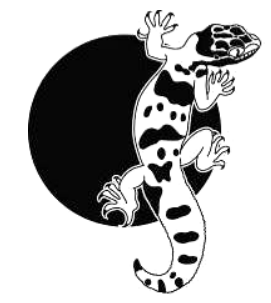

\section{Habitat comparison of Cynopterus fruit bats at Lampung, Sumatra, Indonesia}

Indonesia is home to at least 205 species of bats, over a fifth of the world's total. Chiroptera in the Indonesian island chain belong to nine families and 52 genera (Francis, 2008). Most of these bats are insectivores but the Pteropodidae of sub-Order Yinpterochiroptera are frugivores and nectarivores and, hence, important pollinators of economically significant plants such as petai (Parkia speciosa), durian (Durio zibethinus), mango (Mangifera indica), and kapok (Ceiba pentandra); they also disperse seeds of water apple (Syzygium aqueum), guava (Psidium guajava), and canarium nut (Canarium spp.) (Knauth et al., 1972; Suyanto, 2001). Not only do these pteropodid bats play roles in agriculture and ecosystem continuity, they also figure in the reproductive success of plants and in the regeneration of disturbed areas (Medellin et al., 2000; Bianconi et al., 2007; Kunz et al., 2011).

Bats of the genus Cynopterus are the most common and diverse pteropodids in the Indomalayan Region (Francis, 2008) and new records are still reported from this region. Cynopterus luzoniensis was first recorded in Sulawesi (Maryanto \& Yani, 2003). These bats are tolerant of habitat disruption and disturbance and so are found in agricultural and urban settings as well as the forest. A generalist approach to diet, a keen nose, good flight ability enabling extensive foraging capability, and adaptability regarding roost locations give Cynopterus bats an advantage in surviving well in the habitats they occupy (Corlett, 2004; Castro-Luna et al., 2007; Kunz et al., 2011, Campbell et al., 2006). Nevertheless, there is evidence that this is not the full story because Fenton et al. (1992) showed that fruit bat diversity is higher in tropical forest areas where human disturbance level was low. It is this dynamic that we wanted to test for.
Bukit Barisan Selatan National Park (BBSNP) is a tropical rainforest area in the Sumatran lowland 365,800 ha in extent. Illegal logging in the park is especially evident at edges where villages are separated from the forest by the Pemerihan River in West Lampung (Suyadi \& Gaveau, 2007). This deterioration in habitat conditions may affect populations of fruit bats that pollinate economically significant trees in nearby plantations. We wanted to evaluate the effect of deforestation on Cynopterus fruit bat diversity and numbers with the knowledge that C. brachyotis, C. horsfieldii, and C. sphinx are known pollinating agents (Lasmana, 2008). Research, therefore, was conducted in the BBSNP/agricultural garden ecotone.

Study area (Fig. 1): The study site was located at the edge of BBSNP abutting an adjacent agricultural garden ( $\left.5^{\circ} 36^{\prime} 54^{\prime \prime} \mathrm{S}, 104^{\circ} 23^{\prime} 34^{\prime \prime} \mathrm{E}\right)$. Between the forest and the village was the Pemerihan River as well an asphalt road. The forest edge location will henceforth be referred to as the 'forest' and the local farming area will be referred to as the 'agriculture garden'. The forest edge of BBSNP has had a long history of illegal logging by local people and is consequently classified as secondary forest. The agricultural gardens were located between two villages, Pemerihan and Sumberejo, and grew pepper (Piper sp.), coffee (Coffea sp.), and cocoa (Theobroma cacao) on a commercial basis. Three study sites were set up between the two villages. At each study site, two transects totalling $2 \mathrm{~km}$ were set up at both sides of the edge $(1 \mathrm{~km}$ at agricultural site, $1 \mathrm{~km}$ at forest edge) with $400 \mathrm{~m}$ distance between transects.

Mist-netting: Fruit bats were captured with mist nets (size $6 \times 2.5 \mathrm{~m}$ and $12 \times 2.5 \mathrm{~m}$ ). Mist nets were deployed along the transects at $200 \mathrm{~m}$ intervals resulting in six plots per transect $(1 \mathrm{~km})$ at areas with high intensity of bat use. The height of the mist net was adjusted to the height of understorey. Netting deployment was adjusted to habitat situation. In one location, a 
maximum number of two mist nets were deployed. The nets were combined lengthwise if the plot had a wide opening area. The nets were deployed for 4 hours (18.00-22.00 h) each day. Bats captured were measured (forearm length, thigh length, ear length, and weight), weighed, photographed, identified, then released.

Habitat measurement: Vegetation data was quantified at every mist net location within a $20 \mathrm{~m}$ radius using the Point-Centered-Quartered (PCQ) method. The $20 \mathrm{~m}$ radius circular plot was then divided into four quadrants to assist measurement. Within these quadrants we measured understorey density and canopy closure and then averaged the results. We also measured the distance to the mist net of the four nearest trees and their $\mathrm{DBH}$.

Data analysis: To evaluate the different habitat structures of forest and agricultural gardens we used the t-test. To evaluate bat diversity between the two areas we used the ShannonWiener $\left(\mathrm{H}^{\prime}\right)$ index. To evaluate correlation between bats and habitat structures we used Spearman's rho.

Vegetation Analysis: Our results suggest that forests were denser than the agricultural gardens (Table 1). The percent canopy opening was higher in agriculture gardens (46\%) than forests $(17 \%)$ and the percent understorey cover was lower in agriculture gardens $(11 \%)$ than forests $(62 \%)$. Both canopy openings and understorey densities were significantly different between the two locations (canopy openness, $\mathrm{t}=-2.465$, $\mathrm{P}=0.017$; dense understorey density $\mathrm{t}=11.678$, $P<0.001)$. However, neither forests nor agricultural gardens had any difference in tree DBH $(\mathrm{t}=-0.396, \mathrm{P}=0.693)$ or tree distance $(\mathrm{t}=$ $1.323, \mathrm{P}=0.19$ ).

Cynopterus bat diversity: 166 Cynopterus fruit bats were captured at both forest and agricultural garden locations in 195 hours of capture effort. There were more individuals captured in agricultural gardens (105 individuals) than in forests (61 individuals). Cynopterus species diversity was higher in agriculture gardens $\left(\mathrm{H}^{\prime}=\right.$ $1.11)$ than in forests $\left(\mathrm{H}^{\prime}=0.99\right)$. Four species of Cynopterus bats were apprehended, ie., $C$. brachyotis, C. horsfieldii, C. minutus, and $C$. sphinx (Fig. 2). All four species of Cynopterus are present in both locations although in different proportions. C. brachyotis was the commonest species both in the forest and in agriculture gardens. In the latter habitat $C$. brachyotis, C. horsfieldii, and C. sphinx were the commonest cynopterids whereas $C$. minutus was the commonest species on the forest side. Relationship to habitat structure suggested that only $C$. brachyotis was correlated to more open canopy (Spearman rho 0.466, $P<0.001$ ) and $C$. horsfieldii was correlated to average tree distance (Spearman rho $-0.235, \quad P=0.047$ ) showing preference to less spacious habitat. Others showed no correlations to habitat structures (all with $\mathrm{P}>0.05$ ).

The greater diversity of the Cynopterus species in agricultural gardens was likely due to the concentrated availability of food in such locations (Juste \& de Val, 1995). Forest settings tended to have patchy tree distribution and more complex vegetation while in agricultural gardens trees were more evenly spaced because they were cultivated (Hylander \& Nemomissa 2008).

Table 1: Vegetation structure at forest edge and agricultural gardens adjacent to BBSNP.

\begin{tabular}{|c|c|c|c|c|}
\hline \multirow[b]{2}{*}{$\begin{array}{c}\text { Vegetation } \\
\text { variables }\end{array}$} & \multicolumn{2}{|c|}{ Location } & \multicolumn{2}{|c|}{ t-test } \\
\hline & $\begin{array}{c}\vec{y} \\
0 \\
0 \\
0 \\
0\end{array}$ & 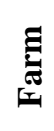 & $H$ & 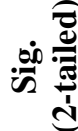 \\
\hline $\begin{array}{l}\text { Canopy } \\
\text { openness } \\
(\%)\end{array}$ & 17 & 46 & -2.46 & 0.02 \\
\hline $\begin{array}{l}\text { Understorey } \\
\text { density }(\%)\end{array}$ & 62 & 11 & 11.68 & 0.00 \\
\hline $\mathrm{DBH}(\mathrm{cm})$ & 16.08 & $\begin{array}{l}16 \\
.0 \\
7\end{array}$ & -0.39 & 0.69 \\
\hline $\begin{array}{l}\text { Tree } \\
\text { distance }(\mathrm{m})\end{array}$ & 2.74 & $\begin{array}{l}2 . \\
34\end{array}$ & 1.32 & 0.19 \\
\hline
\end{tabular}

Morphology measurements showed a range for the four species: C. minutus (FA $=52.7-$ $69.4 \mathrm{~mm} ; \mathrm{W}=20-56 \mathrm{mg})$, C. brachyotis $(\mathrm{FA}=$ $56.2-72.0 \mathrm{~mm} ; \mathrm{W}=22.0-63.5 \mathrm{mg}$ ), C. sphinx $(\mathrm{FA}=68.5-74.8 \mathrm{~mm} ; \mathrm{W}=48.5-67.0 \mathrm{mg})$, and $C$. horsfieldii $(\mathrm{FA}=66.8-78.8 \mathrm{~mm} ; \mathrm{W}=41.0$ $66.5 \mathrm{mg}$ ). Identification followed Suyanto (2001).

Our results show that Cynopterus fruit bats were more prevalent in agricultural gardens adjoining the national park than in the adjacent forest. One cause for this could be that the dense canopy and thicker and lusher understorey in the forest inhibits flight (Hodgkison et al., 2004) of these 
fruit bats because they have to rely on eyesight for navigation (Knauth et al., 1972; Suyanto, 2001; Francis, 2008). Indeed, a thick understorey appears to deter even the more adroit chiropterans that echolocate (Prastianingrum, 2008). Although both forest and agricultural gardens have similar DBH and mean tree distance values, agricultural gardens have a less cluttered understorey in general. Thus vegetation cover is a key factor that could affect bats' flight capability, indirectly affecting their diversity in habitats. Agricultural gardens (13 species) had less tree species than the forest (67 species).

With four medium-sized fruit bat species sharing a given habitat how do they partition resources? It appears that $C$. minutus, with the smallest body, favours the forest, a habitat filled with leaves and twigs and branches, that favours species with smaller wings (Table 2). The larger C. brachyotis, on the other hand, is commoner in disturbed areas or those associated with human activities such as farming (Campbell et al., 2006; Bumrungsri et al., 2007; Jayaraj et al., 2012). This is supported by the correlation of $C$. brachyotis distribution with open areas. $C$. horsfieldii, another large species, is also commoner in agriculture gardens adjacent to forest (Campbell et al., 2006). It appears then that morphology affects the suitability of a habitat for a given species. Heterogeneity of habitat, therefore, can be a factor in promoting fruit bat species diversity (Hodgkison et al., 2004).

Table 2: Comparison of forearm length (FA) mean and individual number of $C$. minutus and $C$. brachyotis between forest and agricultural gardens.

\begin{tabular}{lccccc}
\hline & \multicolumn{2}{c}{ Forest } & & \multicolumn{2}{c}{$\begin{array}{c}\text { Agricultural } \\
\text { gardens }\end{array}$} \\
\cline { 2 - 3 } \cline { 5 - 6 } & $\begin{array}{c}\text { FA mean } \\
(\mathrm{mm})\end{array}$ & $\mathrm{n}$ & & $\begin{array}{c}\text { FA mean } \\
(\mathrm{mm})\end{array}$ & $\mathrm{n}$ \\
\cline { 1 - 2 } $\begin{array}{l}\text { minutus } \\
\text { m. }\end{array}$ & 57 & 27 & & 58,1 & 22 \\
$\begin{array}{l}\text { brachyotis } \\
\text { bryes }\end{array}$ & 65,2 & 28 & & 67,1 & 61 \\
\hline
\end{tabular}

We observed the overlapping of habitat use but there may be partitioning based on the sizes of fruits exploited that reduces interspecific competition. It has been shown that body size of consumer species is correlated to fruit size (Dumont et al., 2003). Small-sized Cynopterus species ( $C$. brachyotis and $C$. minutus) may tend to pick smaller fruit than the larger cynopterids
(C. horsfieldii and C. sphinx). It was further related to fruit bats' habit of carrying fruit to another perch prior to consumption (Tan et al., 2000; Hodgkison et al., 2003). However, the above behaviour was indirectly causing the bats to disperse seed far away from source trees thereby increasing tree reproductive success. Cynopterus fruit bats, especially C. brachyotis, can be considered as pioneers in regenerating degraded or fragmented areas. Pollen was also effectively translocated by fruit bats (Tan et al., 2000).

Nevertheless, in agricultural gardens, human intervention limited the influence of bat dispersal of seeds, fruit, and pollen (Tan et al., 2000: Hodgkison et al., 2003). In contrast, fruit bats may play a crucial role in the regeneration of fragmented habitats and in sustaining genetic diversity amongst wild plants (Fujita \& Tuttle, 1991; Kunz et al., 2011). Aside from a limited role in agricultural areas, the ecological services provided by fruit bats can be regarded as beneficial for humans and for the ecosystem. Therefore, both habitats (forest and agricultural gardens) have the potential to sustain the diversity of fruit bats that provide ecological services while sustaining the forest edge of the national park.

\section{Acknowledgements}

We are grateful to the Rufford Foundation for financial support and the Head of BBSNP for granting necessary permits. We also thank Meyner Nusalawo and Sephy Noerfahmy for guidance and support during data collection; I. S. Wijoyo, R. Sudrajat, Janjiyanto, Mulyoto, and other team members for field assistance. Finally we thank Colin Groves and Ibnu Maryanto for reviewing the manuscript.

\section{Literature Cited}

Bianconi, G. V., S. B. Mikich, S. D. Teixeira, and B. H. L. N. S. Maia, 2007. Attraction of fruiteating bats with essential oils of fruits: A potential tool for forest reforestation. Biotropica, 39: 136140 .

Bumrungsri, S., W. Leelapaibul, and P. A. Racey, 2007. Resource partitioning in sympatric Cynopterus bats in lowland tropical rain forest, Thailand. Biotropica, 39: 241-248.

Campbell, P., N. M. Reid, A. Zubaid, A. M. Adnan, and T. H. Kunz, 2006. Comparative 
roosting ecology of Cynopterus (Chiroptera: Pteropodidae) fruit bats in Peninsular Malaysia. Biotropica, 38: 725-734.

Castro-Luna, A. A., V. J. Sosa, and G. CastilloCampos, 2007. Bat diversity and abundance associated with the degree of secondary succession in a tropical forest mosaic in south-eastern Mexico. Animal Conservation, 10: 219-228.

Corlett, R. T., 2004. Flower visitors and pollination in the oriental (Indomalayan) region. Biological Review, 79: 497-532.

Dumont, E. R., T. H. Kunz, and M. B. Fenton. 2003. Bats and fruit: an ecomorphological approach. Pages 398-429 in T. H. Kunz and M. B. Fenton, editors. Bat ecology. University of Chicago, Chicago.

Fenton, M. B., L. Acharya, D. Audet, M. B. C. Hickey, C. Merriman, M. K. Obrist, D. M. Syme, and B. Adkins, 1992. Phyllostomid bats (Chiroptera: Phyllostomidae) as indicators of habitat disruption in the Neotropics. Biotropica, 24: 440-446.

Francis, C. M., 2008. A field guide to the mammals of South-east Asia. New Holland Publishers, Ltd., London: 392.

Fujita, M. S. and M. D. Tuttle, 1991. Flying foxes (Chiroptera: Pteropodidae): Threatened animals of key ecological and economic importance. Conservation Biology, 5: 455-463.

Hodgkison, H., S. T. Balding, A. Zubaid, and T. H. Kunz, 2003. Fruit bats (Chiroptera: Pteropodidae) as seed dispersers and pollinators in a lowland Malaysian forest. Biotropica, 35: 491-502.

Hodgkison, H., S. T. Balding, A. Zubaid, and T. H. Kunz, 2004. Habitat structure, wing morphology, and the vertical stratification of Malaysian fruit bats (Megachiroptera: Pteropodidae). Journal of Tropical Ecology, 20: 667-673.

Hylander, K., and S. Nemomissa. 2008. Home Garden Coffee as a Repository of Epiphyte Biodiversity in Ethiopia. Frontiers in Ecology and the Environment, 6:524-528.

Juste, J. and J. P. del Val, 1995. Altitudinal variation in the subcanopy fruit bat guild in Bioko Island, Equatorial Guinea, Central Africa. Journal of Tropical Ecology, 11: 141-146.
Knauth, P., D. McAdoo, and P. Jensen, 1972. The illustrated encyclopedia of the animal kingdom. Grolier Enterprise, Inc., New York: 109.

Kunz, T. H., E. B. de Torrez, D. Bauer, T. Lobova, and T. H. Fleming, 2011. Ecosystem services provided by bats. Annuals of the New York Academy of Sciences, 1223: 1-38.

Lasmana, F. P. S., 2008. Jenis - jenis kelelawar penyerbuk dan tumbuhan kiropterofili di Way Canguk, Taman Nasional Bukit Barisan Selatan, Lampung. Skripsi, FMIPA Universitas Padjadjaran, Jatinangor: 107.

Maryanto, I., and M. Yani. 2003. A new species of Rousettus (Chiroptera: Pteropodidae) from Lore Lindu, Central Sulawesi. Mammal Study, 28:111120.

Medellin, R. A., M. Equihua, and M. A. Amin, 2000. Bat diversity and abundance as indocators of disturbance in Neotropical rainforest. Conservation Biology, 14: 1.666-1.675.

Prastianingrum, H., 2008. Keanekaragaman kelelawar pemakan serangga pada jalur baru dan jalur lama di hutan primer Way Canguk, Taman Nasional Bukit Barisan Selatan (TNBBS) Lampung, Sumatera. FMIPA Universitas Lampung, Lampung: 88.

Suyadi and D. L. A. Gaveau, 2007. Akar penyebab deforestasi di sekitar sungai Pemerihan perbatasan Taman Nasional Bukit Barisan Selatan, Lampung Barat. Berita Biologi, 8: 279-290.

Suyanto, A., 2001. Kelelawar di Indonesia. Puslitbang Biologi - LIPI, Bogor: 126.

Tan, K. H., A. Zubaid, and T. H. Kunz, 2000. Fruit dispersal by the lesser dog-faced fruit bat, Cynopterus brachyotis (Muller) (Chiroptera: Pteropodidae). Malayan Nature Journal, 54: 5762.

Submitted: 30 May 2014, Accepted: 16 July 2014 Section Editor: Asoka Yapa

$$
\text { J. Ramadhan }{ }^{1,2} \& \text { N. L. Winarni }{ }^{1,3}
$$

${ }^{1}$ Research Center for Climate Change, University of Indonesia, Gd. PAU Lt. 8.5, Kampus UI, Depok 16424, Indonesia E-mails: jaka_ramadhan@ rocketmail.com², n.winarni@gmail.com ${ }^{3}$ 


\section{PLATE 24}

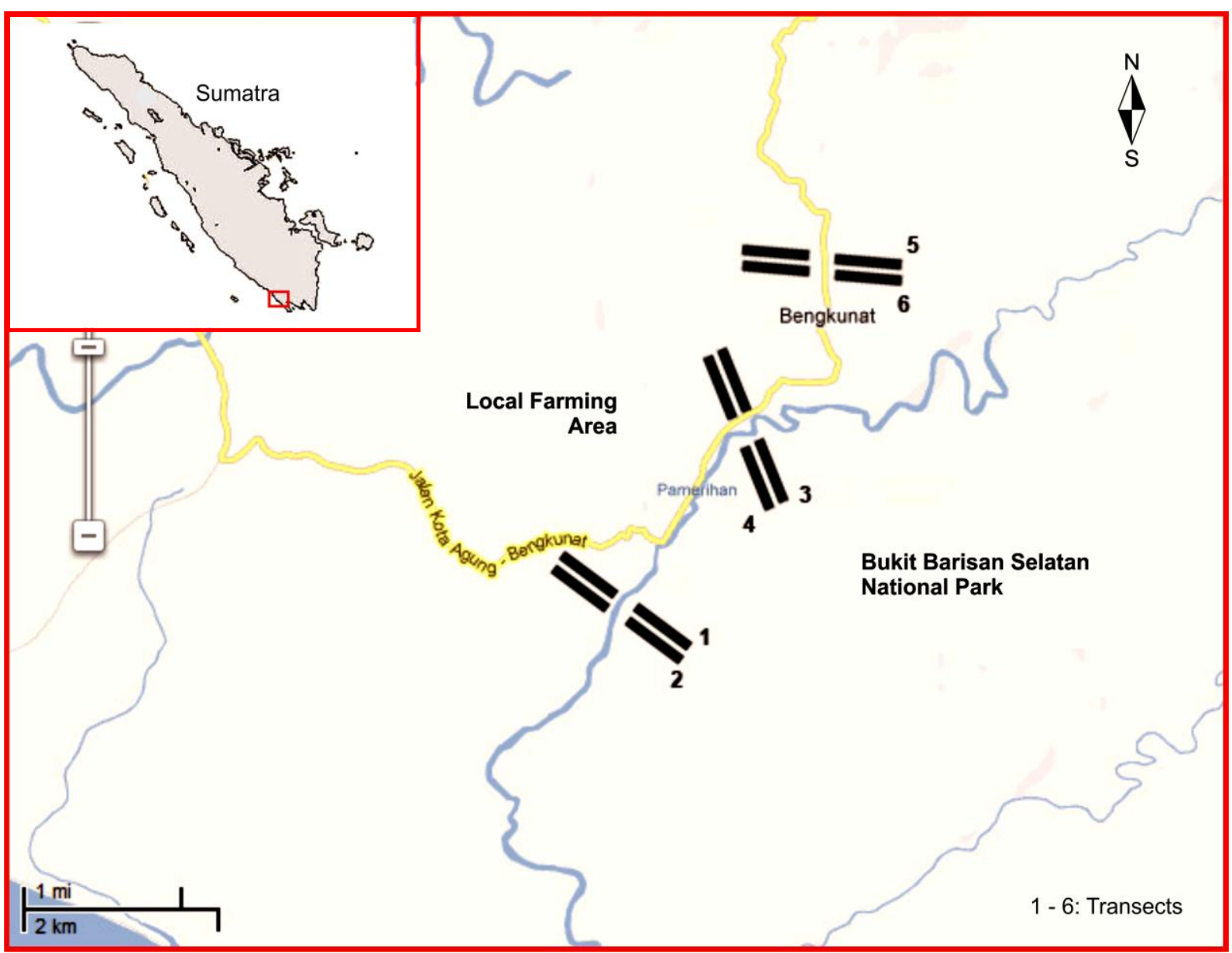

Figure 1: Transect localities at the study site of the BBSNP edge (left upper corner shows Sumatra Island).

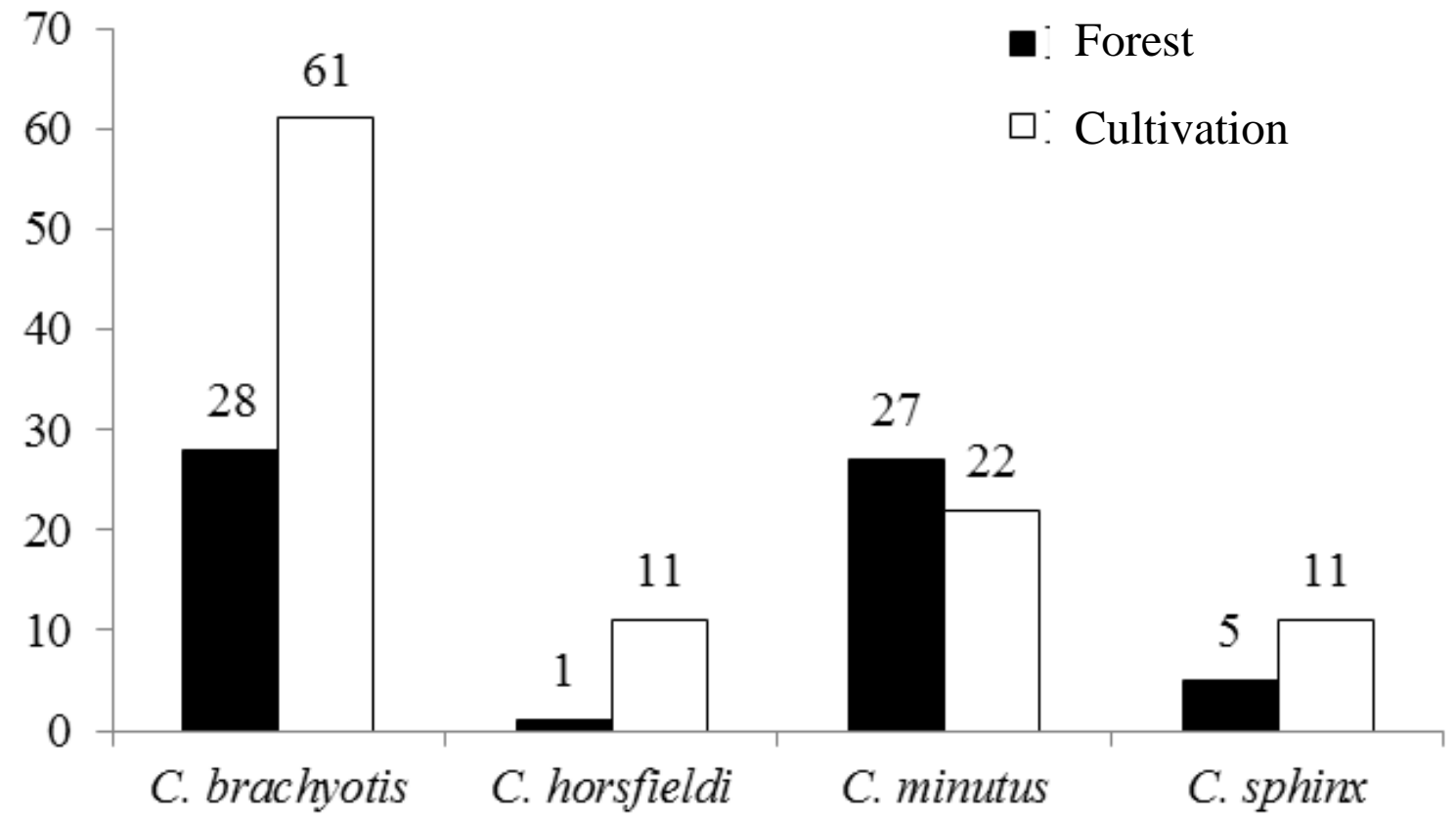

Figure 2: The abundance of Cynopterus fruit bats in the forest and surrounding cultivations of BBSNP 


\section{PLATE 25}
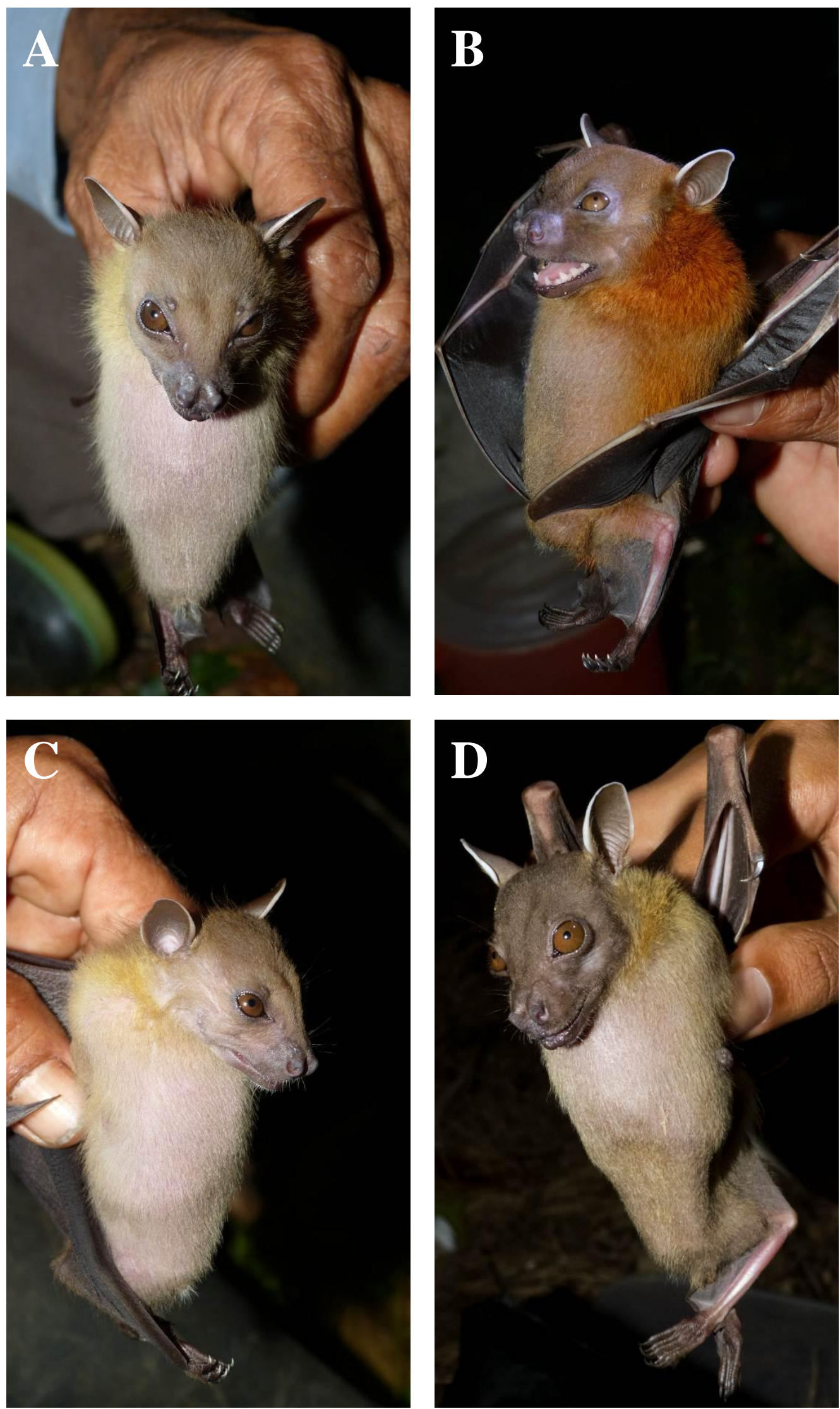

Figure 3: Fruit bats captured at the edge of BBSNP, (A) C. brachyotis, (B) C. horsfieldii, (C) C. minutus, (D) C. sphinx. 